\title{
CHARACTERIZATION OF ACTIVATED BEECH WOOD CHAR - METHANE STORAGE APPLICATION
}

\author{
KATARZYNA PSTROWSKA ${ }^{a, *}, J^{,}$JAN KACZMARCZYKa, \\ HANNA CZAPOR-IRZABEK ${ }^{\mathrm{b}}$, MAREK KUKAŻYŃSKI ${ }^{\mathrm{a}}$
}

\begin{abstract}
Commercial beech wood char characterized by low volatile matter $(5.3 \%)$ and high carbon content $(94.5 \%)$ was initially used as a potential feedstock to obtain the activated carbon for methane sorption. Microand mesopores volumes were determined to be at the level of $0.21 \mathrm{~cm}^{3} \cdot \mathrm{g}^{-1}$, while the specific surface area of the material was determined to be at the level of $416 \mathrm{~m}^{2} \cdot \mathrm{g}^{-1}$. Carbonization carried out at the temperature range of 750$900{ }^{\circ} \mathrm{C}$ resulted in slight increase of the pore volume (up to the value of 0.23 $\mathrm{cm}^{3} \cdot \mathrm{g}^{-1}$ ) and the specific surface area (up to the value of $480 \mathrm{~m}^{2} \cdot \mathrm{g}^{-1}$ ). Upon the steam activation (up to the $50 \%$ loss of the organic mass) the specific surface area increased substantially and was within the range of $887-943 \mathrm{~m}^{2} \cdot \mathrm{g}^{-1}$ together with mico- and mesopores volumes that was within the range of 0.54 - $0.58 \mathrm{~cm}^{3} \cdot \mathrm{g}^{-1}$. The maximum methane adsorption was determined for the sample activated at a temperature of $800{ }^{\circ} \mathrm{C}-17.7 \mathrm{~g} \cdot \mathrm{kg}^{-1}$ with a process reversibility of $84.2 \%$. Considering the beech wood char price, its availability and well-known methods of its surface structure improvement, the obtained active carbons are interesting for their testing on a larger scale.
\end{abstract}

Keywords: adsorption; biomass; active carbon; steam activation; carbonization

\section{INTRODUCTION}

Natural gas, whose main component is methane, is more environmentally friendly and cheaper than traditionally used crude oil-origin fuels [1]. Among all hydrocarbons, methane has the highest hydrogen-tocarbon ratio and consequently a higher research octane number (RON =107).

\footnotetext{
a Wroclaw University of Science and Technology, Faculty of Chemistry, Division of Fuels Chemistry and Technology, Gdańska 7/9, 50-344 Wrocław, Poland

b Wroclaw Medical University, Faculty of Pharmacy, Laboratory of Elemental Analysis and Structural Research, Borowska 211A, 50-556 Wrocław, Poland

*Corresponding author: katarzyna.pstrowska@pwr.edu.pl
} 
Among all hydrocarbon fuels, combustion of methane produces the smallest amount of $\mathrm{CO}_{2}$ for each unit of heat that is released [2].

Four different methods were proposed for the storage of natural gas, i.e., liquefied natural gas (LNG), compressed natural gas (CNG), adsorbed natural gas (ANG) and natural gas hydrate (NGH). Among these, ANG technology enables the greatest efficiency in the storage of natural gas [3]. In a conventional high-pressure storage tank, gas is forced into the tank under pressure. Greater pressures enable larger volumes of gas to be stored in the tank. The maximum pressure, and therefore the volume of gas held in the tank, is limited by the physical properties of the tank and its valve. Microporous materials - methane adsorbents, which are used as a filling of a gas tank may perform two functions: reducing the pressure of gas storage (reasons of the tank user safety) and increasing the volume of the gas storage in the tank (economic reasons - a less frequent exchange/tank filling). Development of efficient and cost-effective adsorbent materials is the key to a successful adsorbed natural gas technology. The most important attributes of commercial ANG sorbent is to have a high surface area per unit mass with regular porous structure, high adsorption capacity, mechanical resistance to pressure variations, and high reversibility of the $\mathrm{CH}_{4}$ adsorption.

The search for suitable porous material in terms of improving ANG storage volumetric energy density and lowering the adsorbent cost to the end user is currently an active area of research. Among different porous materials, metal organic frameworks (MOFs), covalent organic frameworks (COFs), zeolites, and active carbons (ACs) have been intensively examined. MOF chemistry offers potential challenging issues typical to $\mathrm{CH}_{4}$ storage due to their unique modularity, unprecedented tunability, and high degree of porosity combined with diverse framework functionalities. However, the commercial applications of MOFs are still restricted due to their limited mechanical robustness, low density, low volumetric adsorption in a synthesized powder form [4-5]. A comprehensive understanding on stability and performance is required against the typical operating conditions to realize these materials for commercial applications. Also, from the commercial point of view, high production costs strongly limit the possibility of their use. Comparing to all types of other potential sorbents, MOFs are also characterized by other factors such as open metal sites, porosity, topologies and framework densities, which can strongly improve methane adsorption capacity [5-9]. Covalent organic frameworks (COFs) are another class of crystalline materials built from organic linkers, which are made up of light elements $(\mathrm{C}, \mathrm{O}, \mathrm{B}$, and $\mathrm{Si})$ and held together by strong covalent bonds (-O, C-C, B-C, C-N and $\mathrm{C}-\mathrm{Si})$ [10-11]. Compared to MOFs, COF materials are more favorable when accounting for gravimetric uptake of natural gas compounds. Both MOFs and COFs are characterized as 
crystalline, porous types of materials. Nevertheless, the absence of metal elements in the COF structure strongly reduces the synthesis costs of the material. One of the major advantages compared to MOFs is the possibility of obtaining COFs of similar porous structure characterized with a much lower density $[5,10,12]$. Still, a comprehensive understanding on material stability and large-size methods of production is required before the commercial application of COFs can be possible. The other disadvantage of these materials as methane sorbents is the small number of published experimental studies available (calculated vs. experimental results). To a large extent, the methane sorption capacity and the possibility of achieving extensive surface of the COFs is analyzed by computational methods [13-15]. Practical application of these materials therefore requires a considerable intensification of laboratory tests.

Several materials created by nature have a regular structure that can be modified by simple, well-known physico-chemical methods and lead to materials having a well-developed porous structure. Among them, zeolites and carbonaceous materials (as selected biomass materials) play the most important role. As potential methane sorbents, molecular sieves have strong advantages, such as being naturally regular, stable, and controllable channel structures and having similar surface chemical structures [16]. Methane adsorption on natural zeolite adsorbents has been widely investigated, as in case of the use of calculation methods as well as experimental studies, e.g. [17-19]. It was proven that zeolites have relatively high packing densities (compared to ACs) but have lower micropore volumes. In addition, zeolites are extremely hydrophilic and can lose their adsorption capacity for methane with time due to preferential moisture adsorption. On the other hand, it has been shown that ACs are very good adsorbents, presenting the highest ANG energy densities and thus the highest storage capacities. ACs can be essentially microporous materials with low mesoporosity and absence of macroporosity if they are properly prepared. This leads to a high packing density and an important volumetric capacity for methane storage. ACs obtained from biomass are characterized primarily by low price and high availability. Regardless of the above, the primary criterion for the selection of biomass raw material as active carbon is a high carbon content and low volatile matter, which provides stable structure and high production capacity in the process of thermal treatment. Among the many methods used, the most common are chemical activation (mainly with the use of $\mathrm{KOH}$ as activating agent [1,20-22]) and physical activation, where steam and/or $\mathrm{CO}_{2}$ is used ad activation agent, e.g. [23-26]. Textural properties (i.e., adsorption capacity [surface area and micropore volume] or the micropore size distribution) are the main factors responsible for gas uptake. The pores' shape, size, surface area, and mechanical resistance to pressure changes of the material is affected not only by the activation 
method but the reactivity of the material. So far, several biomass materials have been used as AC precursors for methane storage. Coconut shells were used by Azevedo et al. [27] for the preparation of ACs with chemical activation $\left(\mathrm{ZnCl}_{2}\right.$ as the activation agent) followed by physical activation. Depending on the amount of the activating agent, the authors obtained materials characteristic of $1090-2270 \mathrm{~m}^{2} / \mathrm{g}$ BET surface and $80-92 \%$ microporosity. A maximum adsorption of the methane at $25^{\circ} \mathrm{C}$ and 40 bar was demonstrated at the level of ca. $122 \mathrm{mg} / \mathrm{g}$ with almost $94 \%$ reversibility. $\mathrm{KOH}$-activated sugarcane molasses was used by Sreńscek-Nazzal et al. [22]. The highest methane adsorption was measured at the level of ca. $197 \mathrm{mg} / \mathrm{g}$ at $20{ }^{\circ} \mathrm{C}$ and $50 \mathrm{bar}$. BET surface area of the materials obtained at the temperature range of 400 $800{ }^{\circ} \mathrm{C}$ was determined at the level of $413-1202 \mathrm{~m}^{2} / \mathrm{g}$. To the authors' knowledge, ACs were both prepared chemically, as physical activation is mainly used for water purification and removal of specific organic compounds from water or gaseous mixtures. The abovementioned examples of the coconut shells [27] and sugarcane molasses [22] indicate the possibility of obtaining a good sorbent with high sorption methane capacity at a low cost of material production.

This study sought to verify the possibility for using low-cost biomass material as a methane sorbent precursor. High carbon content and low volatile matter were decisive for the use of beech wood char as a commercially available and low-cost material. According to the above comments, the present paper focuses on (1) analysis and discussion of the potential use of beech wood char as an active carbon precursor, (2) analysis of the influence of carbonization and activation parameters on the porous structure of beech wood char and the possibility of using the obtained materials as methane sorbents, including adsorption capacity and reversibility of the process.

\section{RESULTS AND DISCUSSION}

\section{Beech wood char characterization}

The commercial beech wood char material (KB) is characterized by ca. $17 \%$ content of the ballast (the total amount of moisture and ash) and a small amount of volatile matter ( $5.3 \%$ daf, Table 1$)$. A low content of volatile matter shows that the industrial producer of the char used a higher carbonization temperature than the temperature commonly used in case of commercial carbonization (usually used in the range of $500-600{ }^{\circ} \mathrm{C}$ [28]). A higher beech wood carbonization temperature was also confirmed by elemental composition of the material. Such high content of carbon in case of the beech wood char 
was previously observed by Zeng et al. [29] (94.4 wt. \% at the pyrolysis final temperature of $1600{ }^{\circ} \mathrm{C}$ ), and Guizani et al. [30] (ca. 91 wt. \% calculated on dry basis, pyrolysis temperature at the level of $900{ }^{\circ} \mathrm{C}$ ). $\mathrm{KB}$ material containing a small amount of volatile matter and built mainly of carbon meets two basic criteria regarding the proper raw material for the activated carbon production process.

Table 1. Characterization of the beech wood char (KB)

\begin{tabular}{|c|c|c|c|c|c|c|c|c|c|}
\hline \multicolumn{5}{|c|}{ Proximate analysis } & \multicolumn{5}{|c|}{ Ultimate analysis } \\
\hline Moisture,\% & \multicolumn{2}{|c|}{ Ash content, \% } & \multicolumn{2}{|c|}{$\begin{array}{c}\text { Volatile matter, } \\
\%\end{array}$} & $\mathrm{C} \%$ & $\mathrm{H} \%$ & N\% & S\% & O\% \\
\hline analytical & analytical & dry & analytical & $\begin{array}{l}\text { dry } \\
\text { ash } \\
\text { free }\end{array}$ & \multicolumn{5}{|c|}{ dry ash free } \\
\hline 9.8 & 5.7 & 6.3 & 4.5 & 5.3 & 94.5 & 0.5 & 1.2 & 0.5 & 3.3 \\
\hline \multicolumn{10}{|c|}{ Porous structure } \\
\hline & \multicolumn{2}{|c|}{ Micropores } & \multicolumn{5}{|c|}{ Mesopores } & \multirow{2}{*}{\multicolumn{2}{|c|}{$\begin{array}{c}\text { Micro- } \\
\& \\
\text { Mesopores }\end{array}$}} \\
\hline $\begin{array}{c}\text { Pore } \\
\text { width, nm }\end{array}$ & $<0.4$ & $\begin{array}{c}0.4- \\
2\end{array}$ & $2-3$ & $3-5$ & $\begin{array}{l}5- \\
10\end{array}$ & $\begin{array}{c}10- \\
50\end{array}$ & $\begin{array}{l}2- \\
50\end{array}$ & & \\
\hline $\begin{array}{l}\text { Volume, } \\
\mathrm{cm}^{3} \cdot \mathrm{g}^{-1}\end{array}$ & 0.009 & 0.171 & 0.021 & 0.005 & 0.003 & 0.001 & 0.030 & \multicolumn{2}{|c|}{0.210} \\
\hline $\begin{array}{l}\text { Surface, } \\
\mathrm{m}^{2} \cdot \mathrm{g}^{-1}\end{array}$ & 24 & 472 & 17.6 & 2.9 & 0.9 & 0.1 & 21.5 & \multicolumn{2}{|c|}{518} \\
\hline
\end{tabular}

For the determination of the porous structure, $\mathrm{CO}_{2}$ and $\mathrm{C}_{6} \mathrm{H}_{6}$ sorption experiments were performed. Characteristic pore volume and pore surface size of the KB material is presented in Table 1 . The total surface area of the $\mathrm{KB}$ calculated with the BET method was determined at the level of $416 \mathrm{~m}^{2} \cdot \mathrm{g}^{-1}$. Volume and surface areas of the micropores ( $\mathrm{V}_{\text {MIKCO2 }}$ and $\left.\mathrm{S}_{\mathrm{CO} 2}\right)$ available for carbon dioxide and inaccessible for benzene were calculated at the level of $0.180 \mathrm{~cm}^{3} \cdot \mathrm{g}^{-1}$ and $474 \mathrm{~m}^{2} \cdot \mathrm{g}^{-1}$, respectively. The average mesopore diameter $\left(d_{\text {MES }}\right)$ was calculated as $2.79 \mathrm{~nm}$.

Beech wood char is built mainly of large-width micropores available to the benzene molecules. The micropore volumes $(0.4-2.0 \mathrm{~nm}$ width) were calculated at the level of $0.171 \mathrm{~cm}^{3} \cdot \mathrm{g}^{-1}$, which is ca. $81.4 \%$ of the volume of all pores accessible for the adsorption. In a much smaller part, the material consists of mesopores (14.3\%) and sub-micropores (4.3\%). A significant share of micropores of a large volume predicts that the activation process will provide active carbons characterized with large pore volumes and surfaces. 
For the thermogravimetric analysis (TG) of $\mathrm{KB}$, the char was heated in argon in the temperature range of $25-900{ }^{\circ} \mathrm{C}$ at a gas flow rate of $5{ }^{\circ} \mathrm{C} \cdot \mathrm{min}^{-1}$. The resulting mass loss $(U)$ depending on the temperature is shown in Fig. 1. The curve shapes of the TG results (Figure 1) confirm earlier observations that the producer of the beech wood char during the carbonization process used a higher temperature than is usually used. At the initial heating $\left(25-200^{\circ} \mathrm{C}\right)$, only the material moisture was eliminated. In a rather wide temperature range (200 $-650^{\circ} \mathrm{C}$ ), weight loss of the sample was small (weight loss at the level of ca. $3 \%$ of organic matter). A gradual and small weight loss with further increases in temperature up to the value of $900{ }^{\circ} \mathrm{C}$ and after $30 \mathrm{~min}$ at the $900{ }^{\circ} \mathrm{C}$ was reached, and $16.8 \%$ of the sample with respect to the initial weight and $8.3 \%$ of the weight of the sample calculated on a dry, ash-free state was observed.

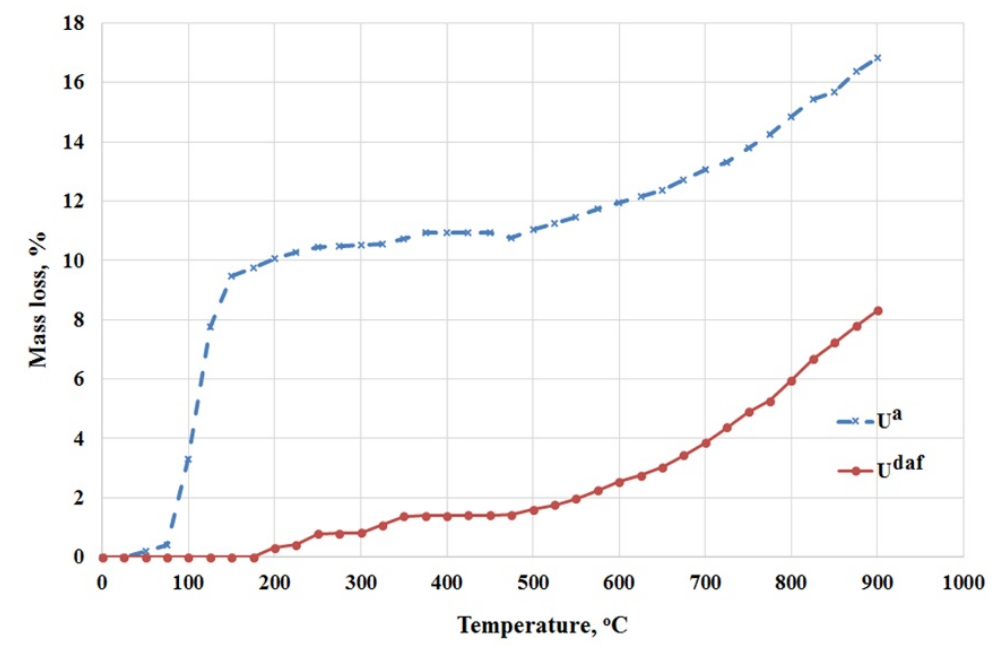

Figure 1. Thermograms obtained under an argon atmosphere and beech wood char (KB) heating

\section{Influence of the carbonization temperature on the porous structure of the beech wood char}

The size and design of the pores in activated carbon is highly dependent on the pore system of the material formed in the carbonization step, which in turn is largely dependent on the carbonization temperature. In the process of char activation, the original porous system is only developed and modified but it is initiated already in the process of carbonization. The temperatures of $750,800,850$ and $900^{\circ} \mathrm{C}$ were applied for optimization of the carbonization final temperature of $\mathrm{KB}$. 
KB was carbonized in the TG apparatus (Figure 3) under an argon atmosphere with a flow rate of $30 \mathrm{dm}^{3} \cdot \mathrm{h}^{-1}$ and heating rate of $10^{\circ} \mathrm{C} \cdot \mathrm{min}^{-1} \mathrm{up}$ to the desired final temperature. At the final carbonization temperature, the material was conditioned for $30 \mathrm{~min}$. The weight loss and yield of the products depending on the temperature of the process is summarized in Table 2.

Naturally, the thermal vulnerability of commercial beech wood char gradually decreases on a scale of rising carbonization temperature. An increase of temperature (from 750 up to $900{ }^{\circ} \mathrm{C}$ ) results in only a $2.5 \%$ weight loss (Table 2), which shows good thermal stability of the KB material. It is worth noting that this small loss contributes no decomposition of organic matter resulting from the supply to the increasing energy but also the inequalities associated with the industrial production cycle of the beech wood.

Table 2. Carbonization of the beech wood char - mass balance of the process

\begin{tabular}{|c|c|c|c|}
\hline Sample & $\begin{array}{c}\text { Final carbonization } \\
\text { temperature, }{ }^{\mathbf{}} \mathbf{C}\end{array}$ & Mass loss, Ua,$\%$ & Yield, \% \\
\hline KB $_{750}$ & 750 & 14.2 & 85.8 \\
\hline KB $_{800}$ & 800 & 15.3 & 84.7 \\
\hline KB $_{850}$ & 850 & 16.5 & 83.5 \\
\hline KB $_{900}$ & 900 & 16.7 & 83.3 \\
\hline
\end{tabular}

Using the obtained carbon dioxide adsorption isotherms of the adsorption/ desorption isotherms of benzene at $25^{\circ} \mathrm{C}$, the volume and surfaces of the microand mesopores were calculated and summarized in Table 3 . The average pore diameter of the mesopores was determined in the range of $3.30-3.51 \mathrm{~nm}$. With increasing carbonization temperature, the average pore diameter decreased. The volume and surface area of the micropores ( $\mathrm{V}_{\mathrm{MIKCO} 2}$ and $\left.\mathrm{S}_{\mathrm{CO} 2}\right)$ available for carbon dioxide and inaccessible to the benzene were as follows:

$\begin{array}{lll}\mathrm{KB}_{750} & \mathrm{~V}_{\text {MIK CO2 }}=0.155 \mathrm{~cm}^{3} \cdot \mathrm{g}^{-1} & \mathrm{~S}_{\mathrm{CO} 2}=408 \mathrm{~m}^{2} \cdot \mathrm{g}^{-1} \\ \mathrm{~KB}_{800} & \mathrm{~V}_{\text {MIK CO2 }}=0.190 \mathrm{~cm}^{3} \cdot \mathrm{g}^{-1} & \mathrm{~S}_{\mathrm{CO} 2}=499 \mathrm{~m}^{2} \cdot \mathrm{g}^{-1} \\ \mathrm{~KB}_{850} & \mathrm{~V}_{\text {MIK CO2 }}=0.175 \mathrm{~cm}^{3} \cdot \mathrm{g}^{-1} & \mathrm{~S}_{\mathrm{CO} 2}=460 \mathrm{~m}^{2} \cdot \mathrm{g}^{-1} \\ \mathrm{~KB}_{900} & \mathrm{~V}_{\text {MIK CO2 }}=0.178 \mathrm{~cm}^{3} \cdot \mathrm{g}^{-1} & \mathrm{~S}_{\mathrm{CO} 2}=468 \mathrm{~m}^{2} \cdot \mathrm{g}^{-1}\end{array}$


Table 3. Porous structure of the materials obtained in the beech wood char carbonization

\begin{tabular}{|c|c|c|c|c|c|c|c|c|c|c|}
\hline \multirow{2}{*}{\multicolumn{2}{|c|}{\begin{tabular}{|c|} 
Pore \\
width \\
\end{tabular}}} & \multicolumn{2}{|c|}{ Micropores } & \multicolumn{5}{|c|}{ Mesopores } & \multirow{3}{*}{$\begin{array}{c}\begin{array}{c}\text { Micro- } \\
\& \\
\text { Mesopores }\end{array} \\
0.196\end{array}$} & \multirow{3}{*}{$\begin{array}{c}\text { SBET } \\
-\end{array}$} \\
\hline & & \multirow{2}{*}{$\begin{array}{c}<0.4 \\
0\end{array}$} & \multirow{2}{*}{$\begin{array}{l}\mathbf{0 . 4 - 2} \\
0.173\end{array}$} & \multirow{2}{*}{$\begin{array}{c}2-3 \\
0.009\end{array}$} & \multirow{2}{*}{$\begin{array}{c}3-5 \\
0.006\end{array}$} & \multirow{2}{*}{$\begin{array}{l}5-10 \\
0.005\end{array}$} & \multirow{2}{*}{\begin{tabular}{|c|}
$\mathbf{1 0 -}$ \\
$\mathbf{5 0}$ \\
0.003 \\
\end{tabular}} & \multirow{2}{*}{$\begin{array}{l}2-50 \\
0.023\end{array}$} & & \\
\hline 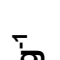 & $\mathrm{KB}_{750}$ & & & & & & & & & \\
\hline$\sum_{0}^{\dot{\xi}}$ & KB800 & 0 & 0.201 & 0.015 & 0.006 & 0.004 & 0.003 & 0.028 & 0.229 & - \\
\hline$\stackrel{\Phi}{E}$ & KB850 & 0 & 0.193 & 0.016 & 0.009 & 0.004 & 0.005 & 0.034 & 0.227 & - \\
\hline गे & KB900 & 0 & 0.192 & 0.019 & 0.007 & 0.006 & 0.005 & 0.037 & 0.229 & - \\
\hline \multirow{4}{*}{ 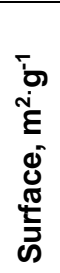 } & KB750 & 0 & 476 & 7.9 & 3.5 & 1.4 & 0.3 & 13.1 & 489 & 427 \\
\hline & KB800 & 0 & 555 & 11.9 & 3.6 & 1.1 & 0.3 & 16.9 & 572 & 496 \\
\hline & $\mathrm{KB}_{850}$ & 0 & 534 & 13.6 & 5.3 & 1.1 & 0.4 & 20.4 & 554 & 479 \\
\hline & KB900 & 0 & 529 & 16.3 & 3.8 & 1.8 & 0.5 & 22.4 & 551 & 480 \\
\hline
\end{tabular}

The data summarized in Table 3 indicate that increasing the temperature of carbonization had a relatively limited effect on the pore structure. Minor differences can be seen in the slightly increased values of the micro- and mesopore volume. As a result of raising the temperature from 750 to $900{ }^{\circ} \mathrm{C}$, the total volume and surface area of the pores were increased slightly in the range of $0.19-0.23 \mathrm{~cm}^{3} \cdot \mathrm{g}^{-1}$ and $490-570 \mathrm{~m}^{2} \cdot \mathrm{g}^{-1}$, respectively. The obtained materials are highly microporous materials from their $84-88 \%$ share in the volume of the adsorption pores. It is expected that the char obtained at the carbonization temperature of $800{ }^{\circ} \mathrm{C}$, which exhibited the highest micropore volumes, may be the best material to obtain activated carbon for gas storage. At the same time, $\mathrm{KB}_{800}$ characterized by the largest BET surface area (496 $\mathrm{m}^{2} \cdot \mathrm{g}^{-1}$ ) of all obtained carbonization products is a promising sorbent material.

\section{Reactivity of the carbonized beech wood char and porous structure modification in the steam activation process}

Isothermal conditions at the temperatures of $750,800,850$ and $900{ }^{\circ} \mathrm{C}$ were applied for the $\mathrm{KB}_{750}, \mathrm{~KB}_{800}, \mathrm{~KB}_{850}$, and $\mathrm{KB}_{900}$ samples for the partial gasification with the use of steam as the activation agent. Preparation of active carbons was conducted up to the organic mass loss at the level of $50 \%$ (calculated to the daf basis). Materials obtained in the physical activation were designated as the following: $\mathrm{KB}_{750 a c}, \mathrm{~KB}_{800 a c}, \mathrm{~KB}_{850 a c}, \mathrm{~KB}_{900 a c}$. 
In Figure 2, reactivity of the carbonized samples in the steam activation process are presented. Table 4 contains some parameters that describe the course of these processes. The curves of isothermal steam activation processes shown in Figure 2 are similar to a straight line, which indicates a constant and similar speed of reaction of carbon material with steam in time. Increase in the temperature accelerates the rate of activation heterogeneous reaction over 9-times; the time to reach $50 \%$ weight loss reduced from 492 minutes $\left(\mathrm{KB}_{750 \mathrm{ac}}\right.$ activated at a temperature of $\left.750{ }^{\circ} \mathrm{C}\right)$ to 53 min (KB ${ }_{900 a c}$ sample activated at a temperature of $900^{\circ} \mathrm{C}$-Table 4).

Table 4. Steam activation parameters up to $50 \%$ of the organic mass loss of the carbonized beech wood chars

\begin{tabular}{|l|c|c|c|}
\hline Sample & $\begin{array}{c}\text { Activation } \\
\text { temperature, }\end{array}$ & $\begin{array}{c}\text { Activation } \\
\text { time, } \mathbf{~ m i n}\end{array}$ & $\begin{array}{c}\text { Average reactivity } \\
\mathbf{R}^{\text {daf }}, \mathbf{g} \cdot \mathbf{g}^{-1} \cdot \mathbf{h}^{-\mathbf{1}}\end{array}$ \\
\hline KB $_{750 a c}$ & 750 & 492 & 0.061 \\
\hline KB $_{800 a c}$ & 800 & 185 & 0.162 \\
\hline KB850ac & 850 & 91 & 0.330 \\
\hline KB ${ }_{900 a c}$ & 900 & 53 & 0.566 \\
\hline
\end{tabular}

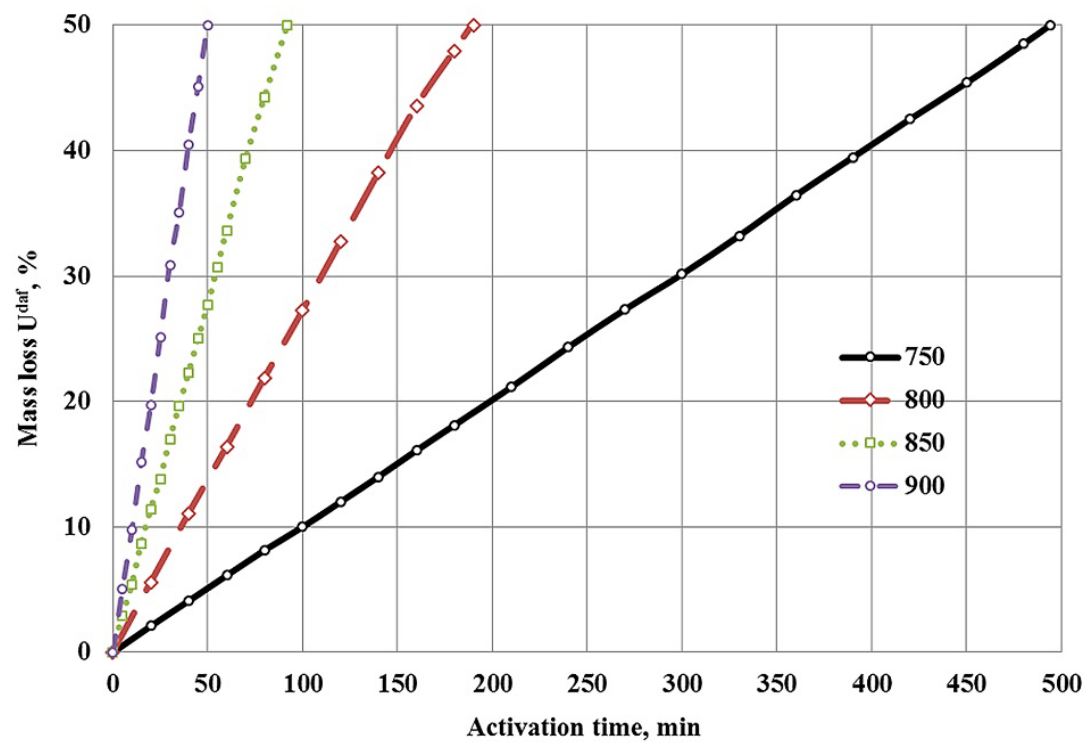

Figure 2. Changes in the samples mass loss during the steam activation of carbonized beech wood char 
Characteristic parameters describing the porous structure of activated carbons, which are calculated on the basis of carbon dioxide and benzene adsorption isotherms, are summarized in Table 5 . The volume and surface area of the micropores $\left(\mathrm{V}_{\mathrm{MIK}} \mathrm{CO}_{2}\right.$ and $\left.\mathrm{S}_{\mathrm{CO} 2}\right)$ available for carbon dioxide compound and inaccessible for benzene were as follows:
$\mathrm{KB}_{750 \mathrm{ac}}$
$\mathrm{V}_{\mathrm{MIK} \mathrm{CO2}}=0.177 \mathrm{~cm}^{3} \cdot \mathrm{g}^{-1}$
$\mathrm{S}_{\mathrm{CO} 2}=466 \mathrm{~m}^{2} \cdot \mathrm{g}^{-1}$
$\mathrm{KB}$ 800ac
$\mathrm{V}_{\text {MIK CO2 }}=0.172 \mathrm{~cm}^{3} \cdot \mathrm{g}^{-1}$
$\mathrm{S}_{\mathrm{CO} 2}=453 \mathrm{~m}^{2} \cdot \mathrm{g}^{-1}$
$\mathrm{KB}_{850 \mathrm{ac}}$
$\mathrm{V}_{\text {MIK CO2 }}=0.171 \mathrm{~cm}^{3} \cdot \mathrm{g}^{-1}$
KB $B_{900 a c}$
$\mathrm{V}_{\mathrm{MIK} \mathrm{CO2}}=0.173 \mathrm{~cm}^{3} \cdot \mathrm{g}^{-1}$
$\mathrm{S}_{\mathrm{CO} 2}=450 \mathrm{~m}^{2} \cdot \mathrm{g}^{-1}$
$\mathrm{S}_{\mathrm{CO} 2}=461 \mathrm{~m}^{2} \cdot \mathrm{g}^{-1}$

Compared to the chars, the main result of the steam activation process was almost two times higher pore volume and a surface area in the obtained active carbons (Table 3, Table 5). The average pore diameter of the active carbon mesopores was determined in the range of $3.54-4.07 \mathrm{~nm}$. Conversely, compared to the carbonization, increase in the activation temperature corresponded to an increase in the average pore diameter of the mesopores. The obtained active carbons are characterized with a relatively large micropore volume $\left(0.34-0.35 \mathrm{~cm}^{3} \cdot \mathrm{g}^{-1}\right)$ and well-developed system of mesopores $\left(0.20-0.23 \mathrm{~cm}^{3} \cdot \mathrm{g}^{-1}-\right.$ Table 5$)$. Considering total surfaces of microand mesopores, which vary in the range of $1044-1092 \mathrm{~m}^{2} \cdot \mathrm{g}^{-1}$ (Table 5), the obtained carbon materials may be considered as high-performance adsorbents. $\mathrm{S}_{\mathrm{BET}}$ level of the active carbons obtained in the steam activation of biomass by other authors can be noted as similar or higher, eg. ACs from giant knotweed, $\mathrm{S}_{\mathrm{BET}}$ below $800 \mathrm{~m}^{2} \cdot \mathrm{g}^{-1}$ [26], millet stalks ACs: $1324 \mathrm{~m}^{2} \cdot \mathrm{g}^{-1}$, rice husk ACs: $384 \mathrm{~m}^{2} \cdot \mathrm{g}^{-1}$, cashew shells ACs: $858 \mathrm{~m}^{2} \cdot \mathrm{g}^{-1}$ [31], coconut shell based ACs: $1499 \mathrm{~m}^{2} \cdot \mathrm{g}^{-1}$, wood-based carbon $970 \mathrm{~m}^{2} \cdot \mathrm{g}^{-1}$ [32].

Table 5. Porous structure of the activated carbons obtained in the carbonized beech wood char steam activation

\begin{tabular}{|c|c|c|c|c|c|c|c|c|c|c|}
\hline \multirow{2}{*}{\multicolumn{2}{|c|}{ Pore width }} & \multicolumn{2}{|c|}{ Micropores } & \multicolumn{5}{|c|}{ Mesopores } & \multirow{2}{*}{$\begin{array}{c}\text { Micro- } \\
\text { \& Mesopores }\end{array}$} & \multirow{2}{*}{$\mathrm{S}_{\mathrm{BET}}$} \\
\hline & & $<0.4$ & $0.4-2$ & $2-3$ & $3-5$ & $5-10$ & $10-50$ & $2-50$ & & \\
\hline \multirow{4}{*}{ 皇 } & KB $750 a c$ & 0 & 0.338 & 0.073 & 0.060 & 0.049 & 0.015 & 0.197 & 0.535 & - \\
\hline & $\mathrm{KB}_{800 \mathrm{ac}}$ & 0 & 0.352 & 0.078 & 0.065 & 0.066 & 0.020 & 0.229 & 0.581 & - \\
\hline & KB850ac & 0 & 0.341 & 0.066 & 0.057 & 0.055 & 0.031 & 0.209 & 0.550 & - \\
\hline & KBgo0ac & 0 & 0.346 & 0.060 & 0.059 & 0.058 & 0.032 & 0.209 & 0.550 & - \\
\hline \multirow{4}{*}{ 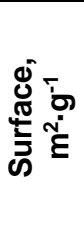 } & $\mathrm{KB}_{750 \mathrm{ac}}$ & 0 & 933 & 61.4 & 33.2 & 15.2 & 1.5 & 111.3 & 1044 & 887 \\
\hline & KB $800 a c$ & 0 & 971 & 64.6 & 35.7 & 19.3 & 1.8 & 121.4 & 1092 & 943 \\
\hline & $\mathrm{KB}_{850 \mathrm{ac}}$ & 0 & 942 & 54.7 & 30.8 & 16.7 & 3.2 & 105.4 & 1047 & 919 \\
\hline & $\mathrm{KB}_{900 \mathrm{ac}}$ & 0 & 956 & 49.5 & 32.7 & 17.3 & 3.3 & 120.8 & 1059 & 928 \\
\hline
\end{tabular}


Increase in the activation temperature by $150{ }^{\circ} \mathrm{C}$ resulted in a significant reduction of the activation time (Table 4). A shorter contact time between the activation agent and the carbonized char did not strongly influence the porous structure of the obtained active carbons. Taking into account the development of the material surface and the amount of specific pore volumes/width (Table 5), it can be noticed that in the range of $750-900{ }^{\circ} \mathrm{C}$ the carbonized beech wood char retains a similar structure. That is why, considering the activation time for the assumed $50 \%$ of organic mass loss, the most economically preferable would be the activation temperature of $900{ }^{\circ} \mathrm{C}$ (the shortest activation time). On the other hand, considering the methane storage, the $\mathrm{KB}_{800 \mathrm{ac}}$ material of the most developed surface area $\left(943 \mathrm{~m}^{2} \cdot \mathrm{g}^{-1}\right)$ and the most developed micromesoporous structure $\left(1092 \mathrm{~m}^{2} \cdot \mathrm{g}^{-1}\right)$, obtained at the activation temperature of $800^{\circ} \mathrm{C}$, is the most preferable.

\section{Beech wood char as methane sorbent}

To evaluate the obtained carbons as methane storage materials, tests of methane adsorption in the sorption apparatus (Fig. 4) were conducted. The following parameters of the test were applied: the temperature of $25^{\circ} \mathrm{C}$ and methane pressure in the range of $0-700 \mathrm{~mm} \mathrm{Hg}$. Based on the determined adsorption/desorption isotherms, the following parameters of the prepared carbons were calculated: the amount of methane adsorbed at the pressure of $700 \mathrm{~mm} \mathrm{Hg}\left(\mathrm{a}_{\mathrm{ad}, 700}, \mathrm{mmol} \cdot \mathrm{g}^{-1} ; \mathrm{g} \cdot \mathrm{kg}^{-1}\right)$; the amount of methane remaining in the pores after desorption process at a pressure of $0 \mathrm{~mm} \mathrm{Hg}\left(a_{\text {des, }, 0} ; \mathrm{mmol}^{-1} \cdot \mathrm{g}^{-1} ; \mathrm{g}^{\cdot \mathrm{kg}^{-1}}\right)$; and the amount of methane desorbed at a pressure of $0 \mathrm{~mm} \mathrm{Hg}\left(\mathrm{a}_{\mathrm{ad}, 700}-\mathrm{a}_{\mathrm{des}, 0}\right.$; $\left.\mathrm{mmol} \cdot \mathrm{g}^{-1} ; \mathrm{g} \cdot \mathrm{kg}^{-1}\right)$. All the obtained results are summarized in Table 6 . The calculation of the $\mathrm{CH}_{4} \mathrm{mmol} \cdot \mathrm{g}^{-1}$ per $\mathrm{g} \cdot \mathrm{kg}^{-1}$ was prepared with the assumption of methane molar mass equal $16.043 \mathrm{~g} \cdot \mathrm{mol}^{-1}$.

Large quantities of methane (about $18 \mathrm{~g}^{\cdot \mathrm{kg}^{-1}}$ ) were adsorbed on the KB surface at a pressure of $700 \mathrm{mmHg}$. Nevertheless, the reversibility of this process is not satisfactory. It can be assumed that the cause of approx. $26 \%$ loss of methane in the desorption process is the geometry of pores (closed or narrow). As expected, the carbonization caused the expansion of the preferred size pores and a greater share of the reversible adsorption. Carbonization at the temperature range of $750-900{ }^{\circ} \mathrm{C}$ resulted in a slight increase in the volume and surface micro- and mesopores (mesopores mainly of the smallest widths: 2 - $3 \mathrm{~nm}$; Table 3). As is already known, these pores play the most significant role in the methane sorption process (microand small mesopores). A significant improvement in the properties of materials caused by carbonization process is evident in the case of reversible 
storage of methane. As the temperature increases, there is an increase in reversibility in the range of $83-85 \%$. The positive effect of higher temperature carbonization was not observed with an amount of methane adsorbed (Table 6). One of the obtained carbonization products, $\mathrm{KB}_{800}$, is characterized with the methane adsorption at the level of ca. $19.1 \mathrm{~g} \cdot \mathrm{kg}^{-1}$ and a process reversibility of $83 \%$ (Table 6 ). It can be considered as a commercial material for methane storage. Assuming that in the gas storage adsorption a crucial role is played by the presence of only micropores and mesopores of the smallest width, the results obtained in this work do not fully confirm such findings. Active carbons obtained in the steam activation are characterized by almost a two-fold higher micropore volume $\left(0.338-0.352 \mathrm{~cm}^{3} \cdot \mathrm{g}^{-1}\right.$ - Table 5) than carbonization products $\left(0.173-0.201 \mathrm{~cm}^{3} \cdot \mathrm{g}^{-1}\right.$ - Table 3). Narrow mesopores $(2-3 \mathrm{~nm})$ were highly developed in the steam activation process and were also involved in the methane sorption.

Table 6. Methane adsorption/desorption results with a use of carbon materials

\begin{tabular}{|c|c|c|c|c|c|}
\hline \multirow{3}{*}{ Sample } & \multicolumn{4}{|c|}{ Amount of the methane } & \multirow{3}{*}{$\begin{array}{c}\begin{array}{c}\text { Reversibility } \\
\text { of adsorption }\end{array} \\
\%\end{array}$} \\
\hline & \multicolumn{2}{|c|}{$\begin{array}{c}\text { Adsorption } \\
\mathrm{p}=700 \mathrm{~mm} \mathrm{Hg}\end{array}$} & \multicolumn{2}{|c|}{$\begin{array}{l}\text { Desorption } \\
p=0 \mathrm{~mm} \mathrm{Hg}\end{array}$} & \\
\hline & $\mathrm{mmol} \cdot \mathrm{g}^{-1}$ & $\mathbf{g} \cdot \mathbf{k g}^{-1}$ & $\mathrm{mmol} \cdot \mathrm{g}^{-1}$ & $\mathbf{g} \cdot \mathbf{k g}^{-1}$ & \\
\hline \multicolumn{6}{|c|}{ Beech wood char } \\
\hline KB & 1.125 & 18.05 & 0.296 & 4.75 & 73.7 \\
\hline \multicolumn{6}{|c|}{ Carbonization products } \\
\hline $\mathrm{KB}_{750}$ & 1.010 & 16.20 & 0.172 & 2.76 & 83.0 \\
\hline$K_{B} B_{800}$ & 1.190 & 19.09 & 0.203 & 3.26 & 82.9 \\
\hline $\mathrm{KB}_{850}$ & 1.095 & 17.57 & 0.188 & 3.02 & 82.8 \\
\hline $\mathrm{KB}_{900}$ & 1.096 & 17.58 & 0.163 & 2.62 & 85.1 \\
\hline \multicolumn{6}{|c|}{ Active carbons } \\
\hline $\mathrm{KB}_{750 \mathrm{ac}}$ & 1.089 & 17.47 & 0.159 & 2.55 & 85.4 \\
\hline $\mathrm{KB}_{800 \mathrm{ac}}$ & 1.102 & 17.68 & 0.174 & 2.79 & 84.2 \\
\hline $\mathrm{KB}_{850 \mathrm{ac}}$ & 1.060 & 17.01 & 0.166 & 2.66 & 84.3 \\
\hline $\mathrm{KB}_{900 \mathrm{ac}}$ & 1.042 & 16.72 & 0.099 & 1.59 & 90.5 \\
\hline
\end{tabular}


Activated carbons are characterized with 3-4 times higher volume of 2-3 nm width mesopores (up to the value of $0.078 \mathrm{~cm}^{3} \cdot \mathrm{g}^{-1}$ in case of KB $\mathrm{K}_{800 \mathrm{ac}}$ sample Table 5) than carbonized beech wood char samples. Nevertheless, the level of methane adsorbed is similar, as in the case of carbonized samples (16.2$\left.19.1 \mathrm{~g} \mathrm{~kg}^{-1}\right)$ and in the case of activated carbons (16.7-17.7 $\mathrm{g}^{\cdot \mathrm{kg}^{-1}}-$ Table 6). These results confirm the findings of other researchers that the storage of methane in the porous material is not only controlled by the micropore volume of the material but that their geometry also plays an important role [33, 34].

\section{CONCLUSIONS}

Commercial beech wood char was initially treated as a potential substrate for receiving the activated carbon for methane sorption.

Commercial beech wood char is characterized by low volatile matter (5.3\%) and high carbon content (94.5\%). The original porous structure of the material is well developed. Micro- and mesoporous volumes were determined at the level of $0.21 \mathrm{~cm}^{3} \cdot \mathrm{g}^{-1}$, while $S_{\mathrm{BET}}$ of the material was determined at the level of $416 \mathrm{~m}^{2} \cdot \mathrm{g}^{-1}$. This material meets all the basic conditions required for precursors of activated carbons. Carbonization conducted at the temperature range of $750-900{ }^{\circ} \mathrm{C}$ did not significantly affect the pore system. The improvement resulted in slightly increasing pore volumes in the range of 0.19$0.23 \mathrm{~cm}^{3} \cdot \mathrm{g}^{-1}$. The most favorable system for methane storage was developed in the carbonization step at a final process temperature of $800{ }^{\circ} \mathrm{C}$. The methane adsorption level was determined as $19 \mathrm{~g} \cdot \mathrm{kg}^{-1}$ with $83 \%$ reversibility of the process. Steam activation of chars were characterized with $\mathrm{S}_{\mathrm{BET}}$ within the range of $1044-1092 \mathrm{~m}^{2} \cdot \mathrm{g}^{-1}$ and micro- and mesoporous volumes within the range of $0.54-0.58 \mathrm{~cm}^{3} \cdot \mathrm{g}^{-1}$. The maximum methane adsorption was determined for the sample activated at a temperature of $800{ }^{\circ} \mathrm{C}-17.7 \mathrm{~g} \cdot \mathrm{kg}^{-1}$ with a process reversibility of $84.2 \%$.

\section{EXPERIMENTAL SECTION}

\section{Beech wood char and active carbons characterization}

As the raw material, a commercial beech wood char (KB) with different grain sizes was used. For the following studies, a 0.5-3.15 mm sieve fraction was isolated. The following analyses were utilized with the carbon material: elemental analysis (CHNS EA 1110 CE Instruments), proximate analysis 
(moisture content according to: ASTM D3173-11, ash content according to: ASTM D3174-12, volatile matter according to: ASTM D3175 - 11), and thermogravimetric studies.

Thermogravimetric studies of the raw materials as well as activated carbon materials were performed using the thermogravimetric apparatus shown in Fig. 3. The apparatus consists of a tubular resistance furnace (1) with the quartz tube (2) positioned coaxially. The furnace is powered from the AC mains by a programmable temperature controller (3). $1 \mathrm{~g}$ of the tested sample was placed in a measuring cell (4) made of a heat-resistant net inside the quartz tube through the hole in the top stopper. The measuring cell was suspended from one of the arms of an analytical balance using a heat-resistant wire (5). For automatic compensation and determination of the changes of sample weight during the test, the second arm of balance was controlled with the use of an electronic photoelectric-electromagnetic starter (6). Changes in the sample temperature were measured using a thermocouple (7) and recorded on a tape using a multi-electronic compensator (8). A determined amount of inert gas (argon) was introduced into the lower part of the furnace using rotameters (9). Argon was purified from traces of moisture and remaining oxygen before entering the furnace. The obtained thermograms showed the loss of weight expressed as a percentage plotted versus the temperature within the range of $20-900{ }^{\circ} \mathrm{C}$ with a heating rate at the level of $5^{\circ} \mathrm{C} / \mathrm{min}$. At the final carbonization temperature of $900^{\circ} \mathrm{C}$, a char was stabilized for 30 minutes.

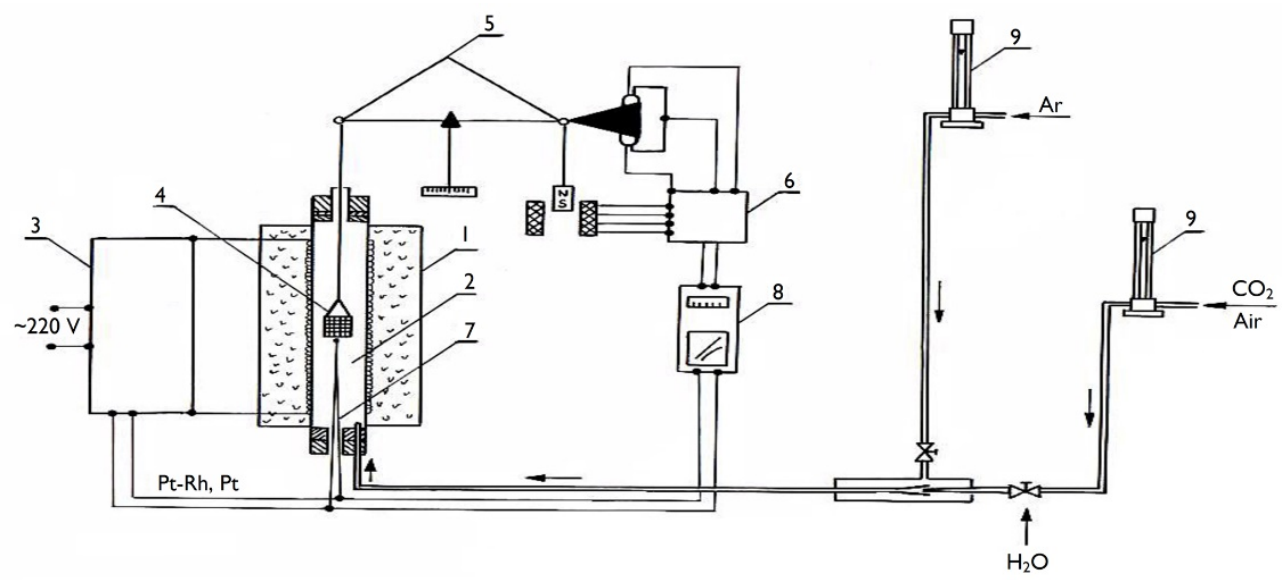

Figure 3. The thermogravimetric apparatus (TG) scheme. (1) tubular resistance furnace, (2) quartz tube, (3) programmable temperature controller, (4) measuring cell, (5) analytical balance, (6) electronic photoelectric-electromagnetic starter, (7) thermocouple, (8) multi-electronic compensator, and (9) rotameter 
The porous structure of the samples was determined at the temperature of $25^{\circ} \mathrm{C}$ in the sorption apparatus (Fig. 4) using the isotherms of carbon dioxide adsorption in the pressure range of the $0-700 \mathrm{~mm} \mathrm{Hg}$ and the adsorption/ desorption isotherms of $\mathrm{C}_{6} \mathrm{H}_{6}$ in the relative pressure range of $\mathrm{p} / \mathrm{p}_{\mathrm{o}} 0-1$.

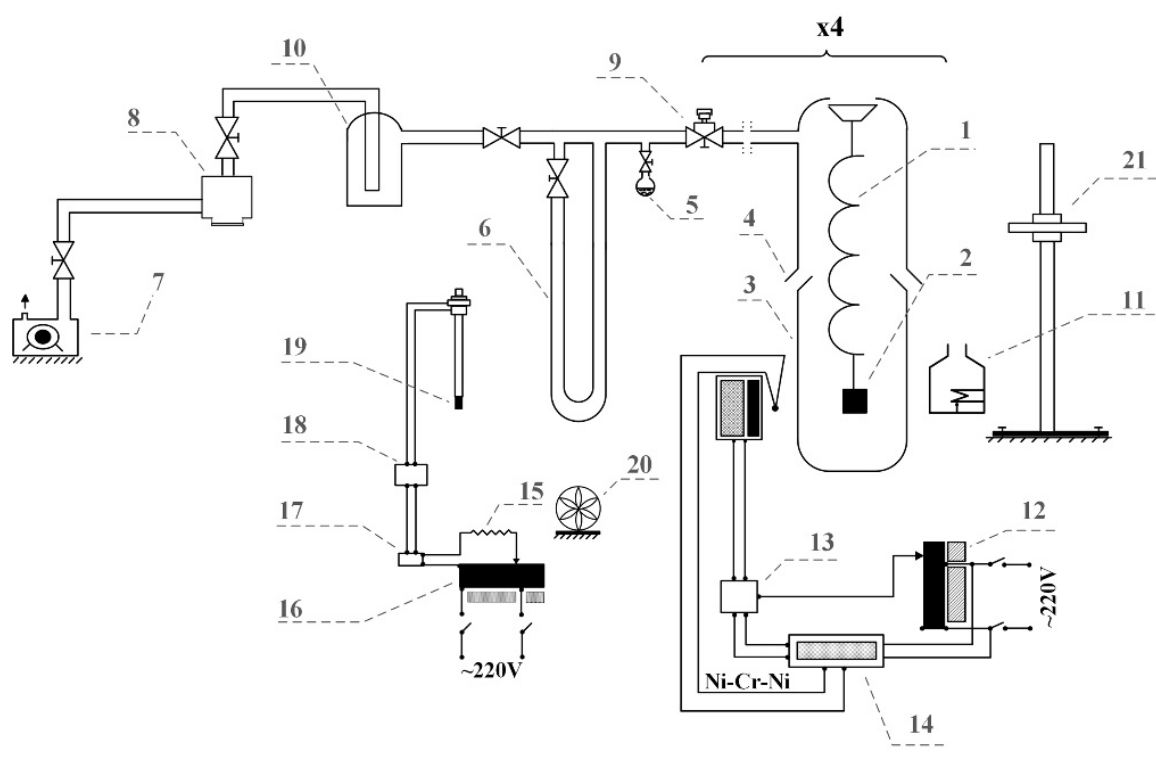

Figure 4. Sorption apparatus scheme. (1) suspended in the glass tube McBain Bakr weight equipment in the form of a quartz spring; (2) quartz flask; (3)(4) glass tubes; (5) adsorbate container; (6) mercury manometer measuring 0-1013 kPa (0-760 $\mathrm{mmHg}$ ); (7) rotary oil pomp; (8) diffusion vacuum pomp; (9) vacuum gauge; (10) freezer; (11) electric resistance furnace; (12) autotransformer; (13) (14) thermocouples connected to the thermoregulatory system; (15) heat exchanger;

(16) thermoregulatory system; (17) contactor; (18) electrical contact; (19) contact thermometer; (20) fan; (21) cathetometer

For the interpretation of the $\mathrm{CO}_{2}$ adsorption isotherms, the theory and equation of Dubinin - Radushkevich (DR) was used [35]. For the DR equation calculations, coefficient $\beta$ affinity was adopted at the level of 0.37 . Using the DR equation, micropore volumes available for carbon dioxide compounds was calculated assuming that each molecule of $\mathrm{CO}_{2}$ at the temperature of $25^{\circ} \mathrm{C}$ is laid flat on the surface of micropores and covers an area of $0.185 \mathrm{~nm}^{2}$ [36].

Brunauer, Emmet, and Teller theory (BET) was used for the interpretation of benzene adsorption isotherm obtained at the relative pressure $\mathrm{p} / \mathrm{p}_{\mathrm{o}}=0.01-0.30$ [37]. The BET method was used for the calculation of the 
material surface $\left(\mathrm{S}_{\mathrm{BET}}\right)$. For the calculations, it was assumed that the surface of the benzene molecule at $25^{\circ} \mathrm{C}$ occupies $0.41 \mathrm{~nm}^{2}$ [38]. Based on the benzene desorption curve in the range of the relative pressure $p / p_{o}=0.96$ 0.175 , the mesopores volume $\left(\mathrm{V}_{\mathrm{MES}}\right)$ and mesopores size distribution $\left(\mathrm{S}_{\mathrm{MES}}\right)$ as a function of width (2-3; 3-5; 5-10 and 10-50 nm) was calculated. The calculations were made according to the Pierce method [39] modified by Orr and Dallavalle [40], considering the amendments on the thickness of the adsorbed layer [41]. The calculations assumed that the pores have the shape of a slot. The average mesopores diameter $\left(d_{M E S}\right)$ was calculated from the following equation: $d_{M E S}=2 V_{M E S}$ : $S_{M E S}$.

Micropore volumes available for benzene vapors $\left(V_{\text {MIK }}\right)$ were calculated as the difference of volume of benzene adsorbed at $\mathrm{p} / \mathrm{p}_{\mathrm{o}}=0.96$ (Gurvich volume $\mathrm{V}_{0.96}$ ) [42] and a previously calculated volume of mesopores: $\mathrm{V}_{\text {MIK }}=\mathrm{V}_{0.96}-\mathrm{V}_{\text {MES }}\left[\mathrm{cm}^{3} \cdot \mathrm{g}^{-1}\right]$. The micropore volumes of the widths below 0.4 $\mathrm{nm}$ (sub-micropores, $\mathrm{V}_{\mathrm{SuB}}$ ) available to smaller molecules of carbon dioxide and inaccessible to larger molecules of benzene was calculated. Submicropore volumes were calculated as the difference of the micropore volume calculated from the $\mathrm{CO}_{2}$ adsorption curve $\left(\mathrm{V}_{\mathrm{MIK}} \mathrm{CO}_{2}\right)$ and the micropore volume calculated from the benzene adsorption curve $\left(\mathrm{V}_{\mathrm{MIK}}\right)$ at $\mathrm{p} / \mathrm{p}_{\mathrm{o}}=0.96 . \mathrm{V}_{\mathrm{SUB}}=\mathrm{V}_{\mathrm{MIK}}$ CO2 $-\mathrm{V}_{\text {MIK. }}$.

\section{Carbonization and physical activation}

Carbonization was operated in the apparatus described in Figure 3 under an argon atmosphere with a flow rate of $30 \mathrm{dm}^{3} \cdot \mathrm{h}^{-1}$ and heating rate of $10^{\circ} \mathrm{C} \cdot \mathrm{min}^{-1}$ up to the final temperature of $750,800,850$ and $900{ }^{\circ} \mathrm{C}$. At the final carbonization temperature, the experiment was held at constant (final) temperature for $30 \mathrm{~min}$ till the carbonization was completed. The obtained materials were cooled in the argon flow up to room temperature. Carbonized materials were designated as the following: $\mathrm{KB}_{750}, \mathrm{~KB}_{800}, \mathrm{~KB}_{850}, \mathrm{~KB}_{900}$.

Carbonized materials were used for the preparation of the active carbon. Physical activation with steam was conducted at temperatures of $750,800,850$ and $900{ }^{\circ} \mathrm{C}$ up to the $50 \%$ organic mass loss of the material (calculated to daf dry, ash free). After reaching the scheduled weight loss, the activating agent was replaced with argon, and the sample was cooled to room temperature. Active carbons were designated as $\mathrm{KB}_{750 a c}, \mathrm{~KB}_{800 a c}, \mathrm{~KB}_{850 a c}$, and $\mathrm{KB}_{900 a c}$. The average reactivity of the samples ( $R^{\text {daf }}$ ) was calculated by dividing the weight of the gasified char $\left(\Delta \mathrm{m}^{\text {daf }}\right)$ by the product of the mass of char applied for the process $\left(\mathrm{m}^{\mathrm{daf}}\right)$ and the activation time expressed in hours $(\mathrm{t})$ :

$$
R^{d a f}=\frac{\Delta m^{d a f}}{m^{d a f_{t}}},\left[g \cdot g^{-1} \cdot h^{-1}\right] .
$$


Both carbonization and physical activation of the beech wood were conducted in the TG apparatus (Fig. 3).

\section{Determination of methane sorption capacity}

To evaluate the obtained carbons as methane storage materials, tests of methane adsorption and desorption were conducted in the sorption apparatus presented in Fig. 4. The following parameters of the test were applied: temperature of $25^{\circ} \mathrm{C}$ and methane pressure range $0-700 \mathrm{~mm} \mathrm{Hg}$. Based on the determined adsorption and desorption isotherms of methane, the following parameters of the prepared carbons were calculated:

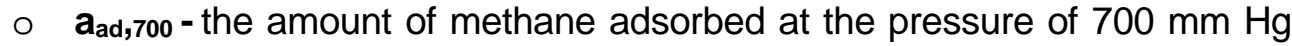
$\left(\mathrm{mmol} \cdot \mathrm{g}^{-1} ; \mathrm{g} \cdot \mathrm{kg}^{-1}\right)$;

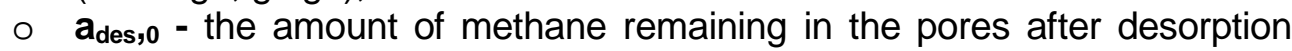
process, at the pressure of $0 \mathrm{~mm} \mathrm{Hg}\left(\mathrm{mmol} \cdot \mathrm{g}^{-1} ; \mathrm{g} \cdot \mathrm{kg}^{-1}\right)$;

$0 \mathbf{a}_{\mathrm{ad}, 700}-\mathbf{a}_{\mathrm{des}, 0}$ - the amount of methane desorbed at a pressure of $0 \mathrm{~mm} \mathrm{Hg}$ $\left(\mathrm{mmol} \cdot \mathrm{g}^{-1} ; \mathrm{g} \cdot \mathrm{kg}^{-1}\right)$.

\section{ACKNOWLEDGMENTS}

This project was supported by the Wroclaw Centre of Biotechnology programme within The Leading National Research Centre (KNOW) and NCBiR Biostrateg project BIOSTRATEG2/298357/8/NCBR/2016.

\section{REFERENCES}

1. D. Lozano-Castello, J. Alcaniz-Monge, M.A.M de la Casa-Lillo, D. CazorlaAmoros, A. Linares-Solano, Fuel, 2002, 81, 1777.

2. S.E. Manahan, "Environmental Science and Technology: A Sustainable Approach to Green Science and Technology", Second Edition, Taylor \& Francis, Boca Raton/USA, 2006, chapter 18.

3. T. Düren, L. Sarkisov, O.M. Yaghi, R.Q. Snurr, Langmuir, 2004, 20, 2683.

4. D. Bazer-Bachi, L. Assie, V. Lecocq, B. Harbuzaru, V. Falk, V., Power Technology, 2014, 255, 52.

5. M.I. Nandasiri, S.R. Jambovane, B.P. McGrail, H.T. Schaef, S.K. Nune, Coordination Chemistry Reviews, 2016, 311, 38.

6. J.A. Mason, M. Veenstra, J.R. Long, Chemical Science, 2014, 5, 32.

7. Y. He, W. Zhou, G. Qian, B. Chen, Chemical Society Reviews, 2014, 43, 5657. 
8. J. Shen, J. Sulkowski, M. Beckner, A. Dailly, Microporous and Mesoporous Materials, 2015, 212, 80.

9. O.M. Yanghi, M. O'Keefe, N.W. Ockwig, H.K. Chae, M. Eddaoudi, J. Kim, Nature, 2003, 423, 705.

10. H. Furukawa, O.M. Yaghi, Journal of the American Chemical Society, 2009, 131, 8875.

11. J.H. Guo, H. Zhang, Y. Miyamoto, Physical Chemistry Chemical Physics, 2013, 15, 8199.

12. H.M. El-Kaderi, J.R. Hunt, J.L. Mendoza-Cortes, A.P. Cote, R.E. Taylor, M. O'Keeffe, O.M. Yanhi, Science, 2007, 316, 268.

13. J.H. Hu, J.F. Zhao, T.Y. Yan, Journal of the Physical Chemistry, 2015, 119 (4), 2010.

14. J.L. Mendoza-Cortes, T.A. Pascal, W.A. Goddard III, Journal of the Physical Chemistry A, 2011, 115, 13852.

15. J. Zhao, T. Yan, RSC Advances, 2014, 4, 15542.

16. X.H. Zhang, Z.Q. Song, X.L. Zhou, C.L. Li, L.Y Xu, Energy Sources, Part A: Recovery, Utilization, and Environmental Effects, 2016, 38(2), 202.

17. T.J. Grey, K.P. Travis, J.D. Gale, D. Nicholson, Microporous and Mesoporous Materials, 2001, 48, 203.

18. R. Hernandez-Huesca, L. Diaz, G. Aguilar-Armenta, Separation and Purification Technology, 1999, 15, 163.

19. M. Sakizci, O.L. Tanriverdi, Turkish Journal of Chemistry, 2015, 39 (5), 970.

20. M.E. Casco, M. Martinez-Escandell, K. Kaneko, J. Silvestre-Albero, F. RodriguezReinoso, Carbon, 2015, 93, 11.

21. D. Lozano-Castello, D. Cazorla-Amoros, A. Linares-Solano, D.F. Quinn, Carbon, 2002, 40, 989.

22. J. Sreńscek-Nazzal, W. Kamińska, B. Michalkiewicz, Z.C. Koren, Industrial Crops and Products, 2013, 47, 153.

23. J. Alcaniz-Monge, M.A. De la Casa-Lillo, D. Cazorla-Amoros, A. Linares-Solano, Carbon, 1997, 35 (2), 291.

24. H.M.B.M. Herath, A.A.P. De Alwis, MERCon 2015 - Moratuwa Engineering Research Conference, article number: 7112310, 2015, available online: http://ieeexplore.ieee.org/stamp/stamp.jsp?tp=\&arnumber=7112310, Accessed 11 March 2018

25. J. Sun, M.J. Rood, M. Rostam-Abadi, A.A. Lizzio, Gas Separation \& Purification, 1996, 10 (2), 91.

26. H. Fałtynowicz, J. Kaczmarczyk, M. Kułażyński, Open Chemistry, 2015, 13, 1150.

27. D.C.S. Azevedo, J.C.S. Araujo, M. Bastos-Neto, E.B. Torres, E.F. Jaguaribe, C.L. Cavalcante, Microporous and Mesoporous Materials, 2007, 100, 361.

28. S. Meyer, B. Glaser, P. Quicker, Environmental Science \& Technology, 2011, 45, 9473.

29. K. Zeng, D.P. Minh, D. Gauthier, E. Weiss-Hortala, A. Nzihou, D. Flamant, Bioresource Technology, 2015, 182, 114.

30. C. Guizani, F.J. Escudero Sanz, M. Jeguirim, R. Gadiou, S. Salvador, Fuel Processing Technology, 2015, 138, 687. 
31. M.M. Dieme, A. Villot, C. Gerente, Y. Andres, S.N. Fiop, C.K. Diawara, Environmental Technology, 2017, 38 (3), 353.

32. E. Lorenc-Grabowska, Adsorption, 2016, 22, 599.

33. K. Sapag, A. Vallone, G.A. Blanco, C. Solar, "Adsorption of Methane in Porous Materials as the Basis for the Storage of Natural Gas, Natural Gas", InTech, Primoz Potocnik (Ed.), 2010, Available from:

http://www.intechopen.com/books/natural-gas/adsorption-of-methane-in-porousmaterials-as-the-basis-for-the-storage-of-natural-gas

34. K. Wu, Z. Chen, X. Li, X. Dong, Scientific Reports, 2016, 6, 33461.

35. M.M. Dubinin, Carbon, 1989, 27, 457.

36. Y. Toda, M. Hatami, Y. Toyoda, Y. Yoshida, H. Honda, Fuel, 1971, 50, 187.

37. S. Brunauer, P.H. Emmet, E. Teller, Journal of the American Chemical Society, 1938, 60, 309.

38. T. Siemieniewska, K. Tomków, J. Kaczmarczyk, A. Albiniak, E. Broniek, A. Jankowska, Y. Grillet, M. François, Studies in surface science and catalysis, 1994, 87, 695.

39. C. Pierce, Journal of Physical Chemistry, 1953, 57, 149.

40. C. Orr, J.M. DallaValle, "Fine particle measurement: Size, Surface, and Pore Volume", The McMillan Company, New York, 1959, chapter 8.

41. S.J. Gregg, K.S. Sing, "Adsorption, Surface Area and Porosity", Academic Press London - New York, 1982, chapter 4.

42. A. Filozof-Nieścior, J. Kaczmarczyk, T. Siemieniewska, Conference on Catalysis and Adsorption in Fuels Processing and Environmental Protection, Kudowa, pp. $69-74$ (2002). 